\title{
Druhé brněnské kolokvium o Leskovovi s pozadím
}

\author{
Ivo Pospíšil (Brno)
}

V roce 2017 pořádal Ústav slavistiky Filozofické fakulty Masarykovy univerzity z iniciativy autora této zprávy v rámci tzv. doktorských škol první mezinárodní brněnské kolokvium o ruském spisovateli 19. století, dříve pozapomínaném, Nikolaji Semjonoviči Leskovovi (1831-1995), který inspiroval ruskou modernu strukturou svých děl a vyprávěcími způsoby, zejména skazem, jenž analyzovali ve svých „parádních“ koncizních studiích ruští formalisté a jenž byl inspirací jak pro ruskou sovětskou avantgardu, tak pro ruskou literaturu mimo Rusko i pozdější tzv. vesnickou prózu typu povídek Vasilije Šukšina (1929-1974). Rok 2017 byl také rokem založení virtuální Mezinárodní společnosti N. S. Leskova se sídlem v Brně, jejíž činnost spočívá v pořádání leskovovských setkání, a hlavně ve vzájemném seznamování s novými pracemi a v rozvoji leskovologie, jak se „vědě o Leskovovi“ poněkud kostrbatě přezdívá.

Druhé brněnské kolokvium - doktorská škola o Leskovovi se konala 5.-6. 11. 2019 (předtím Leskova vystřídal Dostojevskij, z obou kolokvií byly vydány publikační výstupy ${ }^{1}$ ) pod názvem N. S. Leskov a tradice ruského románu ve světovém kontextu. Kolokvia se zúčastnili doktorandi a jejich učitelé a školitelé z České republiky, Ruska a Ukrajiny, mezi nimi editorka Leskovova díla a známí ruští leskovologové. Jazykem kolokvia byla hlavně ruština.

1 Viz Leskov $i$ vokrug. Konteksty tvorčestva $i$ sostojanije sovremennogo leskovovedenija. Ed. Ivo Pospísili. Brno: Ústav slavistiky Masarykovy univerzity, 2018; F. M. Dostojerskij: sostojanije issledovanija i sovremennoje značenije. Eds. L. Paučová - I. Pospísil. Brno: Ústav slavistiky FF MU, vydal Galium-Jan Sojnek, 2019. Viz naše zprávy: Proní brněnské kolokvium o N. S. Leskovovi. Slavica litteraria 21, 2018, č. 1, s. 155-156; Brněnské kolokvium o Dostojevském. Slavica litteraria 22, 2019, č. 1, s. 133-134; Brněnské kolokvikum o N. S. Leskovovi. Novaja rusistika, 2018, č. 1, s. 95-97; Anna Aleksandrovna Fedotova: „Trudnyj rost“: recepcija v proze N. S. Leskova. Jaroslavl: Ministerstvo obrazovanija i nauki Rossijskoj Federacii, Jaroslavskij gos. universitet im. K. D. Ušinskogo “, 2018.
Jak jsme napsali v předmluvě k prvnímu brněnskému svazku o Leskovovi², ruský spisovatel byl dlouho považován za outsidera, neúspěšného, podprůměrného realistického autora často komerčního čtiva. I když se tato charakteristika týká spíše literární kritiky minulosti, faktem zůstává, že se pro řadu ruských prozaiků 19. a 20. století stal právě román nedosažitelným žánrem, zejména román dramatického typu, zvaný často podle jeho nejznámějšího pěstitele balzakovský. Puškinovy románové pokusy jsou dobře známy, ${ }^{3}$ stejně jako jeho podivný „román ve verších“. Ale to se týká také těch, kteří vytvořili poněkud nekonvenční, „umělé“ románové konstrukce, např́iklad M. J. Lermontov s jeho „románem v novelách“. ${ }^{4}$ Tento stav je ovšem úzce spjat s charakterem ruské literatury jako takové, jež stála na křižovatce evropského literárního vývoje. Na jedné straně autochtonní epické struktury a domácí základ románového žánru na čele s protománem Život protopopa Avvakuma jím samým napsaný (167275), jak tvrdil Vadim Kožinov, na druhé straně allochtonní napodobování evropských románových typů, jak se v Rusku objevují po celé 18 . století, např. u otce a syna Fjodora (1735-1770) a Nikolaje (1767-1814) Eminových, Michaila Čulkova (1744-1792), jak se často tvrdívá, autora prvního ruského pikareskního románu Sličná kuchařka aneb Dobrodružná putováni prostopášné ženy (Пригожая повариха, или Похождения развратной женщины, 1770), napsaného, jak se zdá, podle vzoru Defoeova románu Štěstí a neštěstí Moll Flandersové (The Fortunes and Misfor-

2 Leskov $i$ vokrug. Konteksty tvorčestva $i$ sostojanije sovremennogo leskovovedenija. Ed. Ivo Pospíšil. Brno: Ústav slavistiky FF MU, 2018.

3 Viz POSPÍŠIL, Ivo: Romannaja oderžimost' Aleksandra Puškina. Zagadnienia Rodzajów Literackich, 49, z. 1-2, 2006, s. 5-22.

4 Viz POSPÍŠIL, Ivo: Roman $v$ novellach $i$ roman-chronika (Zametki o dofferenciacii russkogo sovetskogo romana). Ruský jazyk, 1981, č. 2, s. 49-54. 
tunes of the Famous Moll Flanders, 1722), ale jde asi jen o syžetovou shodu, nebot první ruský překlad vyšel až 1896 a americká edice dokonce až 1930 - to vše z cenzurních důvodů. Zralejšími výtvory jsou ovšem až Karamzinův evropský cestopis, tak brilantně analyzovaný německým slavistou Hansem Rothem ${ }^{5}$, a Radiščevův románový pamflet vyzývající k společenskému převratu skrytý za vylíčením cesty z Petrohradu do Moskvy. Proces, jenž Vadim Kožinov (1930-2001) kdysi nazval ruskou renesancí (od poloviny 18. po první třetinu 19. století, rámcováno jmény Lomonosova a Puškina) ${ }^{6}$, tedy zvláštní most, který vedl od evropského středověku k renesančně humanistické epoše přes manýrismus, baroko a rokoko ke klasicismu, jenž je však podle Kožinova j směrem jen hypotetickým, nazývám prae-post efekt (paradox $)^{7}$, tedy nedokonalá imitace coby napodobování západoevropských románových modelů, nese s sebou otevření „okna“ do jiných dimenzí poetiky a vytváření nové literatury, včetně nových typů románu, jak nás o přesvědčuje Vojna a mír, Zločin a trest a Bratři Karamazovovi a také románová díla Leskovova. Navíc nelze si za půlstoletí osvojit všechny směry evropských literatur za několik století, takže se toto „osvojení“ odehrává dál v několika vlnách, jak o tom spekuloval Kožinov, jenž v tom však viděl autentické směry, jako by jejich raná podoba v Rusku nebyla (klasicismus Puškinův vedoucí k postromantismu a ranému realismu, baroko u Gogola, sentimentalismus u mladého Dostojevského aj.). V tomto ohledu je Leskov názorným příkladem. Jeho žánrové experimenty netřeba dokumentovat, stejně jako jeho individuální pojmenovávání literárních žánrů, včetně jejich orálního a lidové-

5 ROTHE, Hans: N. M. Karamzins europäische Reise: der Beginn des russischen Romans. Bad Homburg, Berlin und Zürich, 1968.

6 KOŽINOV, Vadim: $K$ sociologii russkoj literatury XVIII$X I X$ vekov (K probleme literaturnych napravlenij). In: Literatura i sociologija. „Chudožestvennaja literatura“. Moskva, 1977, s. 137-177.

7 Viz o tom dvě studie POSPÍŠIL, Ivo: Problema struktury, funkcii $i$ ispolzovanija literaturovedčeskich terminov: po sledam sobstvennych popytok. Mirgorod, 2016 n. 2 (8), s. $26-$ 31; týž: Labyrinty literárněvědné terminologie. Philologia XXVIII/2, časopis Ústavu filologických štúdií Pedagogickej fakulty Univerzity Komenského v Bratislavě, s. 7-20. ho rázu (skaz, črta, vzpomínka, legenda, kronika, pohádka, rapsodie, obrázek podle skutečnosti, pozorování, pokusy, duchařský př́ípad, povídka na hrobě, půlnoční vidění, heraldická kauza, bukolická povídka na historickém základě). ${ }^{8}$

V našich četných knihách a studiích, zejména v malé leskovovské monografii ${ }^{9}$, jsme došli k závěru, že v Leskovově tvorbě lze sledovat dvojí žánrový zlom a to vše se projevilo také ve skladbě druhého brněnského kolokvia o románu leskovovského typu.

Fantastické je, že se Leskov s úporností jen jemu vlastní celý život snažil vytvořit tradiční balzakovský román a vždy neúspěšně. $\mathrm{V}$ první fázi to byly antinihilistické romány, které již na počátku nezapřou kronikální strukturu, v další fázi to jsou typické románové kroniky (zejména Soborjane, 1872), nakonec delší prózy připomínající pohádku (Čërtovy kukly a Sokolij perelët). Románové experimenty někdy připomínají rčení „z nouze ctnost“, ale nakonec tak poskytl rozsáhlý materiál k rozvíjení teorie románu a přemýšlení o románech obecně, stejně jako jiné slovanské literatury, ale ruská zvláště. ${ }^{10}$

Editorka Leskovova díla a badatelka o Leskovovi Alla Šelajevová (Sankt-Petěrburg) hovořila právě o západoevropských kořenech Leskovova románu Čërtovy kukly (česky asi Čertovská kvítka) v referátu Западноевропейские корни романа $H$. C. Лескова Чёртовы куклы: Проблемы , второго пола“ и рещепты их решения. Ukrajinská badatelka Olha Červinska (Černivci, rus. Černovcy, čes. Černovice

8 Viz monografie POSPÍŠIL, Ivo: Proti proudu (Studie o N. S. Leskovovi). Brno: Sprint-Print, 1992) a Rozpětí žánru. Brno: Sprint-Print, 1992); viz také studii týž: Jukstapozicionnaja poetika N. S. Leskova (konstruirovanije obraza pravednika, skazovo-anekdotičeskaja cep', ekzotizm i obrazy inostrancev). Universalii russkoj literatury 5. Sbornik statej. Voronež: Izdateĺsko-poligrafičeskij centr „Naučnaja kniga“", 2013, s. 170-176.

9 Viz již naši diplomovou a rigorózní práci Románová tvorba N. S. Leskova, rkp., UJEP, Brno 1975, a Typologie a poetika Leskovovy románové kroniky, rkp., Brno 1975 a další knihy a studie uvedené jinde.

10 Viz stat POSPÍŠIL, Ivo: Vozdejstvije russkoj literatury $i$ russkogo literaturovedenija na mirovoj literaturnyj process. In: Česká slavistika 2018. Eds. I. Pospíśil - M. Zelenka L. Paučová. Brno: Česká asociace slavistů ve spolupráci se Slavistickou společností Franka Wollmana, Jan Sojnek-Galium, 2018, s. 157-177. 
v Bukovině) a její žák Roman Dzyk pojednali o kyjevských topografických souvislostech Leskovova díla ve společném vystoupení Топографический nортрет Киева: жанровая спечифика текста H. Лескова Печерские антики. Petrohradský historik Leonid Vyskočkov se zabýval tématem Krymské války ve fragmentech románu Čërtory kukly, Roman Dzyk v samostatném vystoupení Украинизмы в Печерских антиках Николал Лескова se vrátil - tentokrát z jazykovědného úhlu - k tématu Leskov a Ukrajina, královéhradecká rusistka Galina Kosych, která se Leskovem zabývala ještě v době svého působení ve Volgogradě, pojednala o Leskovových románech v recepci literární kritiky, Tatjana Melnik/Melnyk (Moskva) vystoupila s př́íspěvkem Культурные смыслы литературного текста (по рассказу Н. С. Лескова Запечатленный ангел). Početná skupina účastníků byla z Jaroslavli; byla reprezentována Světlanou Rodonovovovu, která analyzovala dvojici pojmů a jejich význam, v Leskovově povídce v referátu Лексика со значением «сватовство» и «супружество» в Жемиужном ожерелье Н. С. Лескова. Tatjana Jurjevová sledovala vztah duchovenstva a světské moci v kronice $S_{0}$ borjaпе ("Для нас, духовных, нет защитников»: отражение взаимоотношений духовенства и светской власти в пореформенной России в романе-хронике H. С. Лескова «Соборяне») a Natalja Lukjančikovová analyzovala postavu nihilistky také v románové kronice Duchovenstvo sborového chrámu (Soborjane, jinak Služebníci chrámu) v př́íspěvku s názvem Художественная репрезентачия образа нигилистки в романе-хронике H. С. Лескова Соборяне, Polina Kubyševa ukázala na kontinuitu Leskovova skazu v tvorbě sovětského autora Borise Pilňaka (povolžský Němec Wogau) v referátu Лесковский сказ в твориестве Б. А. Пильняка а Irina Šustinová se orientovala na jazykově poetologické téma (Tunъ и функиии эпитетов в Леди Макбет Миенского уезда Н. С. Лескова). Jediný slovenský účastník, slovakista Pavol Markovič z Prešovské univerzity přispěl studií se zajímavým názvem Leskovova „črta“ Lady Macbeth ako priklad kultúrneho a žánrového presahu. Naděžda Danilovová (Sankt-Petěrburg) demonstrovala to, že Leskov - možná více než ze znalosti ruského lidu, jak mu to mnozí včetně M. Gorkého podsouvají, se opíral o literární zdroje (Литературные источники хроники Н. С. Лескова Захудалый род). Jelena Kažukalová (Sankt-Petěrburg) ukázala zase na vizuální poetiku kroniky Soborjane (Изобразительная поэтика романа-хроники Н. С. Лескова Соборяне), Natalija Nikorjak (Černivci) si všimla meziuměleckých vazeb a adaptací slavné Leskovovy novely (Лedu Макбет Миенского уезда: интермедиальный диалог Н. Лескова и Р. Балаяна), brněnská badatelka Lenka Paučová upozornila na žánrové specifikum Tuberozovova deníku (Жанровая спешифика дневника Туберозова в структуре романа-хроники Соборяне) a Ivo Pospísil se zamyslel nad inspirativními momenty Leskovových románů pro rozvoj teorie románu (Лесков и теория романа). Kromě parciálních diskusí, které provázely každý blok, obvykle sestávající ze tří až čtyř referátů, tu byl workshop, jehož se zúčastnili všichni přítomní včetně hostů, mezi nimiž byli magisterští studenti a doktorandi Ústavu slavistiky FF MU. Zkoumání díla N. S. Leskova i v souvislosti s jeho moravským překladatelem A. A. Vrzalem (A. G. Stinem) bude v různých rámcích i v projektu Mezinárodní společnosti N. S. Leskova se sídlem v Brně pokračovat.

\section{prof. PhDr. Ivo Pospíšil, DrSc.}

Ústav slavistiky

Filozofická fakulta, Masarykova univerzita

Arna Nováka 1, 60200 Brno, Česká republika

ivo.pospisil@phil.muni.cz

Toto dílo Ize užít v souladu s licenčními podmínkami Creative Commons BY-SA 4.0 International (https://creativecommons.org/licenses/by-sa/4.0/legalcode). Uvedené se nevztahuje na díla či prvky (např. obrazovou či fotografickou dokumentaci), které jsou v díle užity na základě smluvní licence nebo výjimky či omezení přislušných práv. 